\title{
INFECTIONS OF THE HAND
}

\author{
J. B. Loudon, J. D. Miniero, and J. C. Scott, Oxford, England \\ From the Accident Service, Radcliffe Infirmary, Oxford (Director-J. C. Scott)*
}

From January 1945 to December 1946, 723 patients with infections of the hand attended the Casualty Department of the Radcliffe Infirmary, Oxford. This represented a loss of 104,112 man-hours, or the equivalent of five months' work for one hundred men. That these infections account for serious clinical problems is generally recognised, but the number of man-hours which is lost is not appreciated fully.

We have been impressed by the large number of hands which despite treatment were damaged beyond repair, both functionally and cosmetically. This was sometimes due to neglect in treatment, but in other cases it was the inevitable result even after the early application of all methods in current use. These patients were the most regular attenders at the Casualty Department. Their dressings required changing, sometimes more than once daily. Frequent dressings were not only painful, but they often led to secondary infection of the wound. Almost invariably they involved many hours of travelling and waiting, and much expense. This paper is presented with the object of stressing the economic importance of infections of the hand; of reiterating the necessity for early treatment; and of indicating the results of a method of treatment which has been in use for the last six months. The main departure from accepted principles has been that instead of performing incision and drainage, excision and suture was carried out wherever possible.

\section{CLASSIFICATION OF CASES}

Fingers : 1) Pulp infection-a) distal ; $b$ ) middle; $c$ ) proximal.

2) Paronychia.

3) Dorsal space infection-a) middle; $b$ ) proximal.

Hand : 4) Distal palmar pulp infection (" web space infection ").

5) Thenar space infection.

6) Mid-palmar space infection.

7) Hypothenar space infection.

8) Dorsal space infection-a) subcutaneous, $b$ ) subaponeurotic.

9) Tendon sheath infection.

No case of infection of the radial or ulnar bursa was seen in six months.

Based on the most constant symptoms and signs, and for ease of description, we have divided all finger and hand infections into four degrees:

First degree - Throbbing and tenderness;

Second degree-More marked pain, redness, swelling and heat, tenderness and fluctuation; Third degree - Pain, redness, swelling, fluctuation, heat, tenderness, and devitalised skin; Fourth degree- " The discharging hand "; pain not so marked but sinus present.

With the third and fourth degrees there may also be clinical or radiographic evidence of destruction of deep tissues.

Etiology-In half the series of sixty-nine cases, there was no history of injury. When there was no trauma, minor cut, puncture wound, or blister, it seems probable that the infection was often blood-borne, particularly in distal pulp infection of the fingers. The incidence does not appear to vary with the time of year, nor with the type of peripheral circulation, but it is clearly related to the occupation of the patient. Housewives were most often affected (Table I). Bacteriology - A pure growth of staphylococcus aureus was cultured in 87 per cent. of the cases. The remaining ones grew staphylococcus aureus and B-haemolytic streptococcus $(6.5$ per cent.), or they were sterile $(6 \cdot 5$ per cent.). In the very large majority the organisms were sensitive to penicillin.

* Received for publication, February 14, 1948.

vol. $30 \mathrm{~B}$, No. 3 , AUgust 1948 


\section{PATHOLOGY}

The initial lesion in infections of the hand consists of a group of organisms surrounded by an area of reaction. As in all infections, subsequent events depend upon the result of a conflict between the general and local resistance; and upon the type, virulence, and number of the invading organisms.

In fascial space infections the lesion consists of three distinct zones: $a$ ) a central zone with pus under tension-the result of death of cells at the site of entry of the invading organisms; $b$ ) a middle zone of tissues not yet transformed into pus but already undergoing necrosis; $c$ ) a peripheral zone where the tissues are viable, but are subjected to considerable tension due to increased blood flow and oedema, surrounded by normal tissue (Fig. 1).

Progressive tissue necrosis, with increased extra-vascular fluid in the immediate vicinity, leads to increasing tension which interferes seriously with blood supply and local resistance, thereby establishing a vicious circle. The resulting spread of tissue necrosis is irregular, and is governed largely by the power of resistance of the tissues and by the local anatomical arrangements.

1st DEGREE
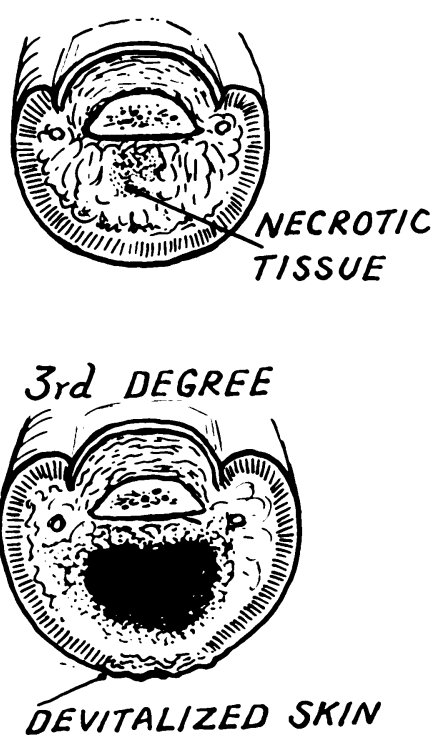

2nd DEGREE

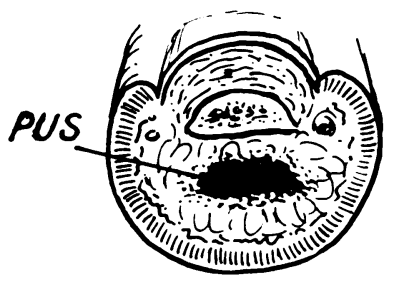

4th DEGREE

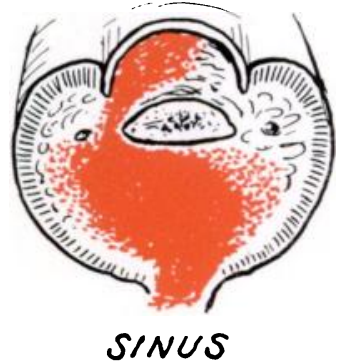

FIG. 1

Pulp Space Infection.

Sometimes the symptoms are more pronounced at a distance from the initial lesion, as in the case of distal palmar pulp infections. We have found that in this type the initial lesion is always in the distal palmar pulp, over the base of the proximal phalanx, the web space being infected secondarily (see Case history 3 ). The signs are more marked in the web space by reason of the laxity of tissues.

In tendon sheaths, infection has invariably spread throughout the length of the sheath by the time that a diagnosis is made. Where infection has spread from neighbouring tissues, or where it is due to a wound, the severity of the destructive process may be much more pronounced at the site of original infection than in the rest of the sheath; but necrosis may occur at a point distant from the initial focus of infection, where overlying structures compress the swollen and oedematous tendon and sheath. The pathology of tendon sheath infections will be described later in more detail. 
TREATMEN T

Aims of treatment-The aims of treatment are two-fold: 1) Surgical-a) to secure routine early and adequate surgical intervention, with elimination of the methods of blind surgery; b) to avoid spread of infection, and secondary infection, consequent upon the use of drains and the methods of frequent dressing; $c$ ) to secure first-intention healing; 2) Economicby these methods to minimise permanent loss of function, reduce loss of man-hours, conserve hospital facilities, and save unnecessary cost to the community.

Method of treatment-The principles of treatment are based upon: 1) evacuation of pus; and 2) excision of necrotic tissues. When using an adequate exposure with a bloodless field the necrotic area can be seen clearly. Excision takes the place of the usual process by which dead tissues are eliminated by discharge. Healing is thereby accelerated. Moreover, the best possible conditions are provided for control of residual infection by the striking and immediate improvement in local blood supply after relief of tension.

Skin cover-Immediate or early skin cover is the best defence against secondary infection; moreover it minimises the amount of scarring. Primary suture is therefore carried out whenever possible, the tissues being protected thereafter from the trauma of movement by immobilisation in plaster. When immediate skin cover is not possible, early skin grafting should be used, the principle of infrequent dressing and plaster protection being employed meanwhile because it not only encourages healing but reduces the incidence of secondary infection. Early healing is the key to recovery of function. Nothing but harm can result from attempts to persuade a patient to move a finger in which there is still infection.

\section{PRE-OPERATIVE TREATMENT}

Under ideal conditions, a patient with spreading infection and general reaction should be admitted to hospital. Unfortunately, shortage of hospital beds has been such that some patients in this category were necessarily treated as out-patients. Those who were admitted, including all patients with cellulitis, had full investigation including urine analysis, differential blood count, blood culture, and estimation of penicillin-sensitivity of the organisms.

Before operation the affected part was immobilised by means of a plaster slab, and elevated either by pillows or slings. Vitamins A, C, and D were given together with copious fluids and 50,000 units of penicillin three-hourly. Reflex vasodilatation was sometimes produced by a heat-cradle over the trunk or lower limbs, but any value that this procedure may have had was outweighed by increased local discomfort.

These measures improved the general condition and controlled the spread of infection, but they failed to influence the local lesion, however small, in which death of tissue had already occurred. As soon as the general condition was improved, the infection circumscribed, and the blood penicillin level sufficiently high-usually within twenty-four hours of admissionoperation was undertaken (see Case histories 68 and 69). About 20 per cent. of the patients who were treated as out-patients were given 200,000 units of sodium penicillin three hours before operation, but this did not seem to influence the result and we now operate on outpatients without routine pre-operative treatment.

\section{OPERATIVE TREATMENT}

Theatre preparation-Strict asepsis, proper instruments, and the aid of an assistant are essential. General anaesthesia must be used. Pentothal, nitrous oxyde, and oxygen are satisfactory anaesthetic agents even for out-patients. The instruments which should be available include: a pneumatic tourniquet, C.T.A.B. for skin preparation, Baird Parker's No. 11 and No. 15 blades, Poirier's 5-in. peritoneal forceps, Michel toothed and plain forceps,

vol. $30 \mathrm{~B}$, No. 3 , AUGUST 1948 
Mayo straight and curved scissors, mosquito forceps, No. 19 curved triangular needles, Grade 3N nylon, penicillin powder, calico, plaster of Paris (2-in. bandages).

The patient is anaesthetised. The limb is elevated for three minutes (held by the tip of the fingers in order to avoid obstruction of the venous circulation). The tourniquet is inflated quickly to a level above that of the systolic blood pressure. The skin is prepared with cetyl trimethyl ammonium bromide, and acriflavine in spirit.

Incisions-The main concern must be not only to gain free exposure of the lesion, but to retain free blood supply to the skin and underlying tissues, and to secure good functional and cosmetic results. These aims can best be achieved by the use of skin flaps turned back

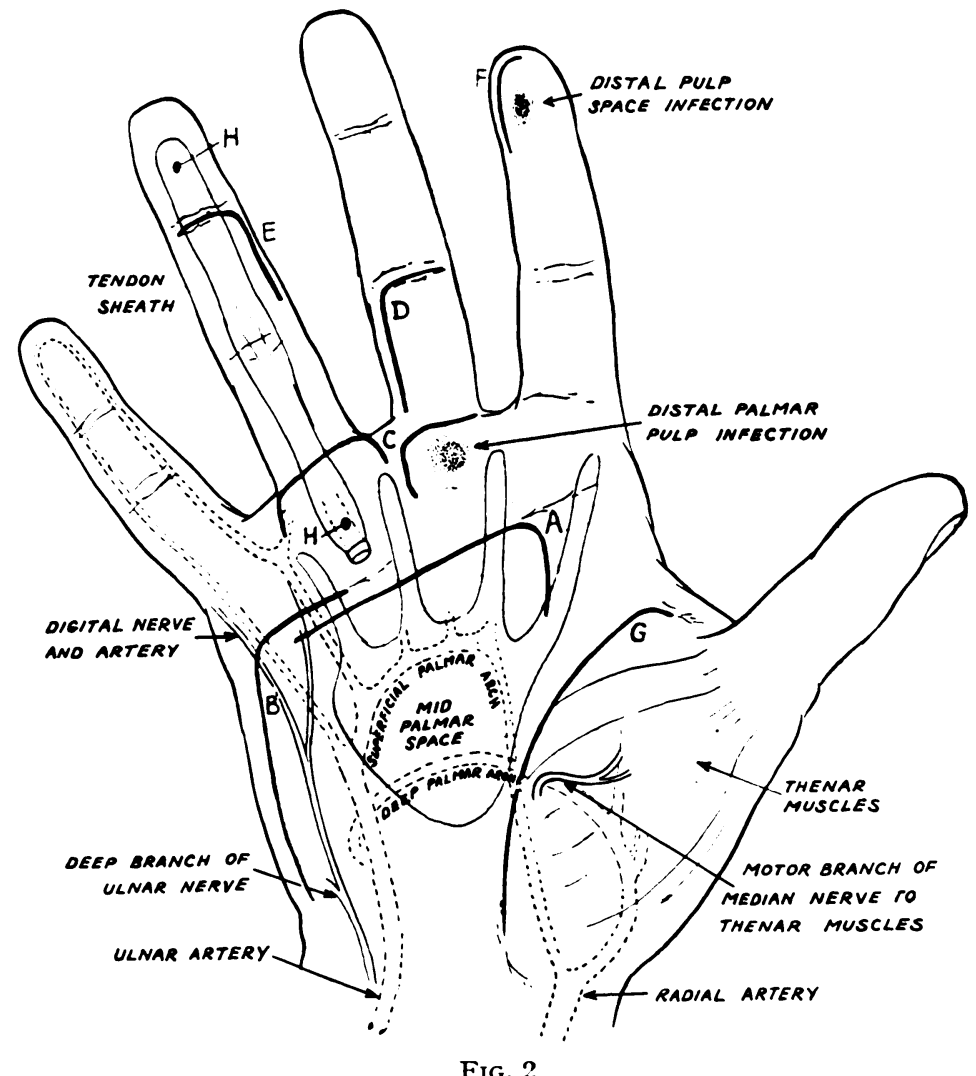

Incisions in relation to underlying structures.

from curved incisions placed in the skin creases, parallel to skin creases, or remote from skin creases (Figs. 2, 3, 4, and 5). In this way even the most gravely contracted scar never interferes seriously with function. Whenever possible we use incisions in the creases, thus gaining the additional advantage of leaving a scar which is unnoticeable. If there is a sinus, one limb of the incision must pass through it (in or parallel to a crease) and the necrosed edges must be excised conservatively. The ideal is to leave no dead skin and to remove no living skin. The skin must be handled gently, the full depth of subcutaneous tissue being mobilised with it. Poirier's five-inch peritoneal forceps, placed at least a quarter of an inch from the skin edge and kept in position throughout the operation, are ideal. The same incisions are used when there are areas of necrosed skin but skin grafting may subsequently be necessary.

The incision used for thenar space infections is shown in Fig. 2G. It is placed parallel to and on the radial side of the adductor skin crease, thus avoiding the danger of opening 
the mid-palmar space. It maps out a flap which gives ample exposure of the thenar space. It is possible to prolong the incision proximally or distally to the dorsum of the hand. The motor branch of the median nerve to the thenar muscles, and the superficial branch of the radial artery, can be seen and avoided without difficulty.

Fig. 2 shows the incisions used: a) for mid-palmar space infection, the palmar fascia being divided on the line of fibres; $b$ ) for hypothenar space infection; $c$ ) for distal palmar pulp infection (with this incision we expose both the web space and the primary lesion over the base of the first phalanx; it may be extended as shown); $d$ and $e$ ) for proximal and middle pulp space infection (in middle pulp space infection the transverse limb must be cut with

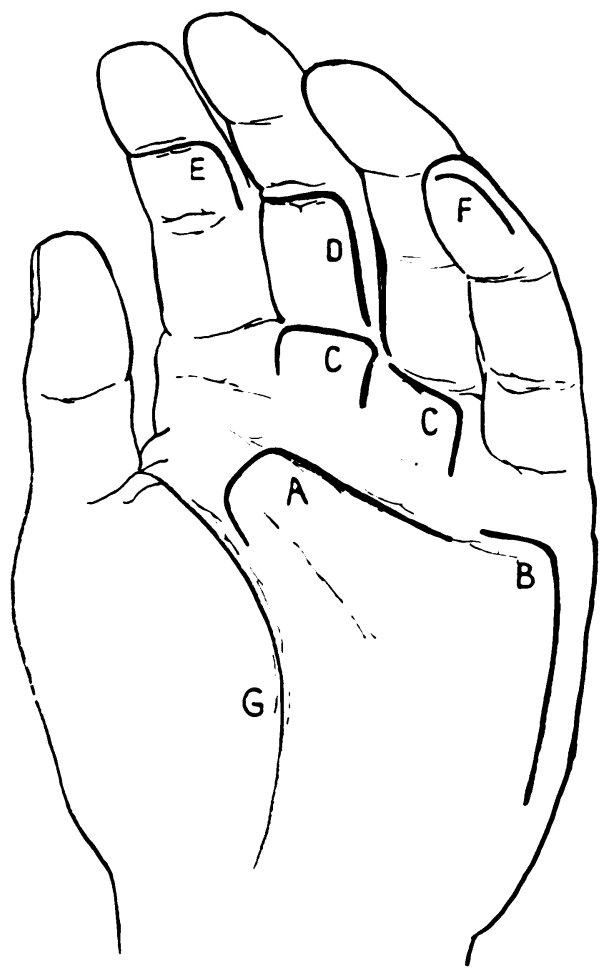

FIG. 3

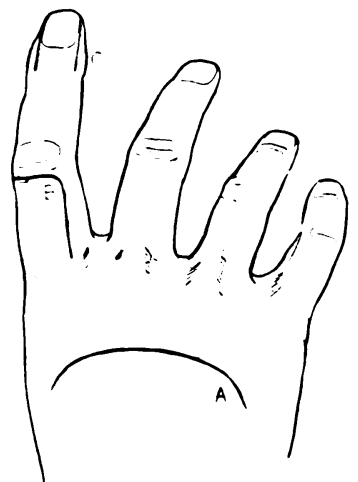

FIG. 4

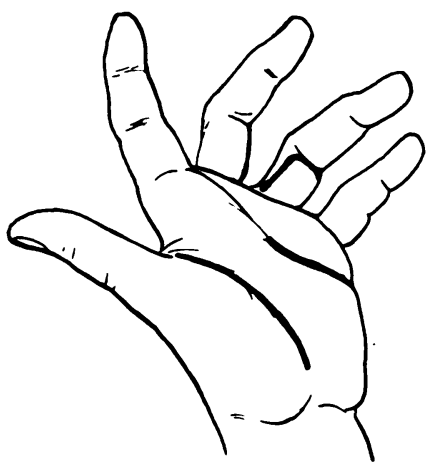

FIG. 5

Incisions in relation to skin creases.

care owing to proximity of the tendon sheath at the distal flexor crease); $f$ ) for terminal pulp space infection (this incision gives adequate exposure for excision in almost all cases, and is to be preferred to the "alligator-mouth" incision which is liable to cause delay in healing because of more extensive interference with blood supply to the skin edge). The incisions used for dorsal space infections and paronychiae are shown in Fig. 4.

Operative procedure-The skin flap is lifted and the incisions are prolonged as necessary. The edges are retracted with Poirier's forceps, thus exposing the devitalised tissues. Pus is evacuated. Necrotic tissues, recognised by their colour, are then excised by holding them with toothed Michel forceps and cutting with Mayo curved scissors. If there is infection of bone with sequestrum formation the dead bone is removed. After excision, a thin layer of penicillin powder is insufflated and the flap is sutured without tension with grade $3 \mathrm{~N}$ nylon in a No. 19 triangular curved needle. Thick coverings of penicillin powder are to be avoided because they retard healing. 
The tourniquet is released only after suture is complete. Since all the vessels have been seen and avoided, no ligatures are required. A dry calico dressing is applied. The affected part, and no more than the affected part, is then immobilised in plaster. A finger may be immobilised adequately by means of anterior and posterior plaster slabs held lightly in place by a moistened gauze bandage. Vaseline gauze and elastoplast coverings are not advisable because they cause maceration of the skin, permit movement, and do not prevent secondary infection.

\section{POST-OPERATIVE TREATMENT}

Immobilisation is continued until healing has taken place. Elevation is essential. Active exercises of the parts which are not immobilised should be encouraged from the beginning. Oedema is controlled by elevation of the limb and by active exercises. Ambulatory patients are given a sling and it is pointed out to them that the hand must always be kept at a higher level than the elbow. In bed the hand must be slung, or rested on a high pillow. Out-patients are instructed to report at once if symptoms are not relieved by the operation. No patient in this series found it necessary to seek an earlier appointment than had been arranged. All were comfortable and needed only to attend for the twice-daily injections of 200,000 units of sodium penicillin for five days after operation. Three patients were given sulphadiazine and attended only a week afterwards for inspection of the wounds, having had four days of chemotherapy. Three were treated without chemotherapy and healed by primary intention.

Elevation and immobilisation should continue until swelling has disappeared and the wound is healed-usually within ten days. Sutures should not be removed in less than seven days. Gentle use of the digit is encouraged as soon as the wound is healed, even before removal of the sutures. Full movements were regained in all cases by ordinary use of the hand, except in the case of two patients who needed physiotherapy (Cases 62, 65).

Particular care is necessary when there is necrosed skin. As soon as the wound is clean and granulating, skin grafting should be carried out under local anaesthesia. Pinch grafts, taken from the inner surface of the arm, have been used. Immobilisation in plaster was continued for another eight to ten days. Intensive active exercises were then started.

\section{TENDON SHEATH INFEGTIONS}

In considering the treatment of tendon sheath infections brief discussion of the etiology and pathology is necessary. In five of our cases the signs could not be correlated with the pathology of tendon sheath infection alone since there was an accompanying lesion, the signs of which were superimposed on those of the sheath infection, giving a combined clinical picture.

There are four main ways in which tendon sheath infection may arise, and there are four degrees of such infection: 1) the infection may be carried to the tendon sheath in the blood stream; 2) there may be lymphatic spread of infection from a neighbouring infection; 3) there may be direct erosion of a sheath underlying a fascial space infection; 4) there may be infection due to direct trauma from a wound, usually over a flexor crease, which may or may not have healed before the sheath infection becomes manifest.

Whatever the etiology, reaction to infection occurs with oedema of the tendon and sheath, and exudate formation within it, the whole sheath being distended with thin, clear fluid. This constitutes a first degree infection (see Case 60, Figs. 7, 8). At this stage the diagnosis can usually be confirmed only by exposure of the sheath which is best carried out through a short transverse incision over the distal end ("observation incision "). If it is found to be distended with exudate, and to have lost its normal transparency, the sheath is opened and washed out with saline from the proximal end by introducing a needle (Fig. 6). 


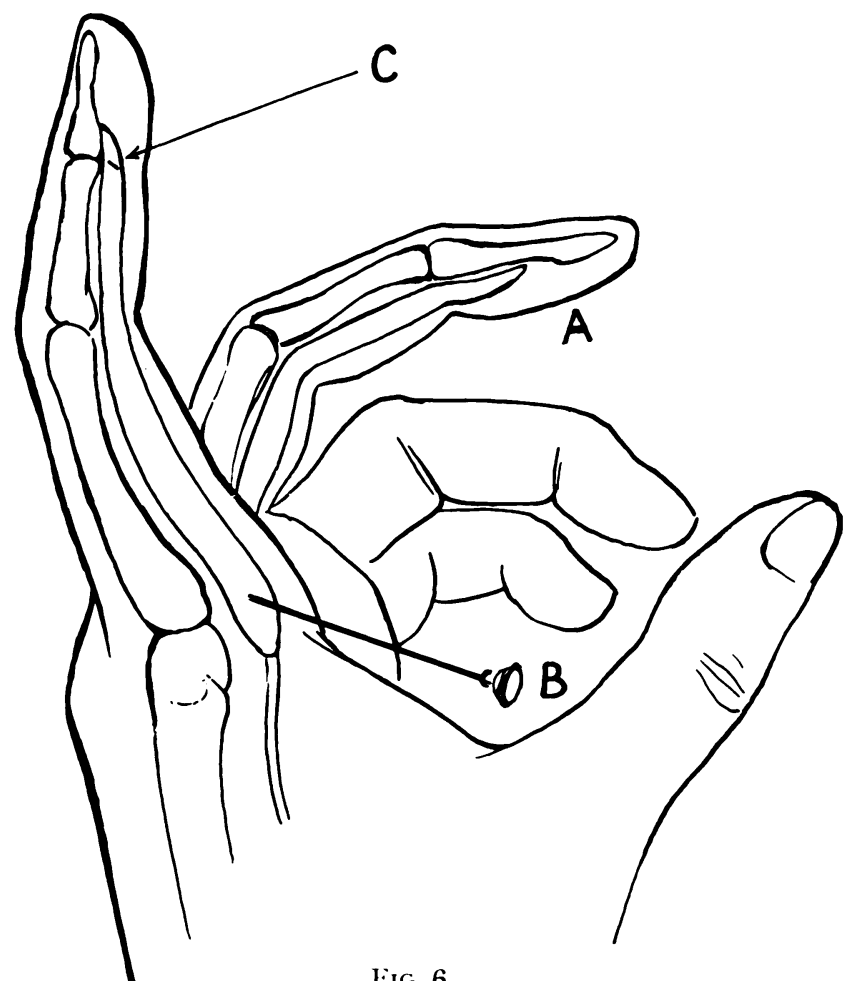

Fig. 6

Method of irrigation of first and second degree tendon sheath infections.

C-site of observation incision; B-needle introduced for irrigation of sheath; A-alternative site for irrigation.

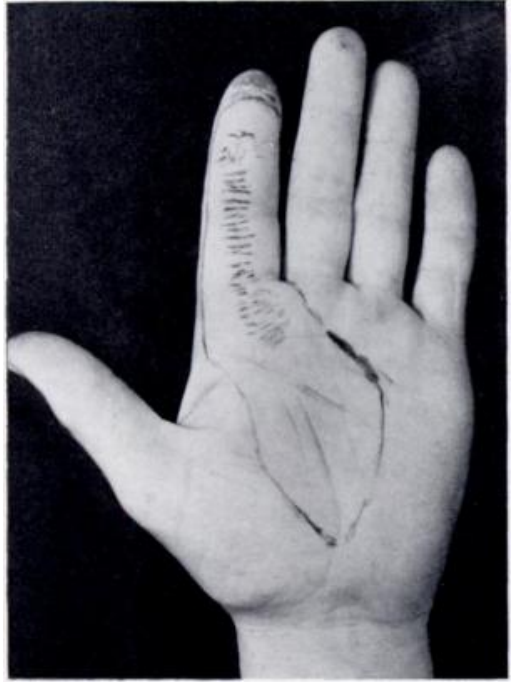

IFIG. 7

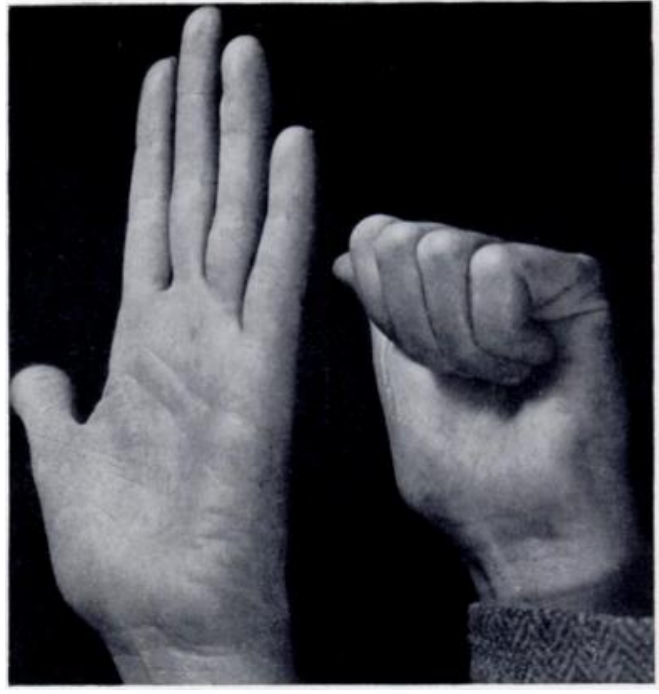

FIG. 8

(ase 60. First degree tendon sheath infection showing area of pain and tenderness (Fig. 7) and the same hand after treatment by irrigation (Fig. 8). 
When the needle is in the sheath no resistance is felt to injection, but if difficulty is encountered the proximal end of the sheath can be exposed through a short transverse incision, parallel and distal to the distal palmar crease. Using the same needle, 100,000 units of sodium penicillin in 5 c.c. of distilled water are injected into the sheath and the observation incision is closed. Second degree tendon sheath infection is present when the thin, clear fluid is replaced

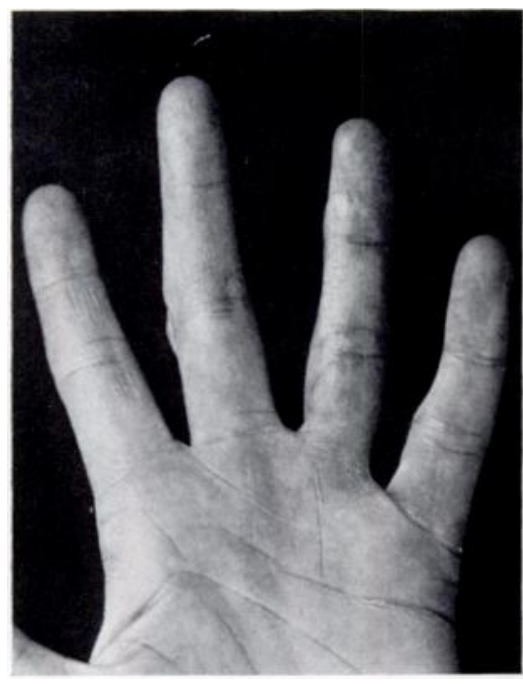

FIG. 9

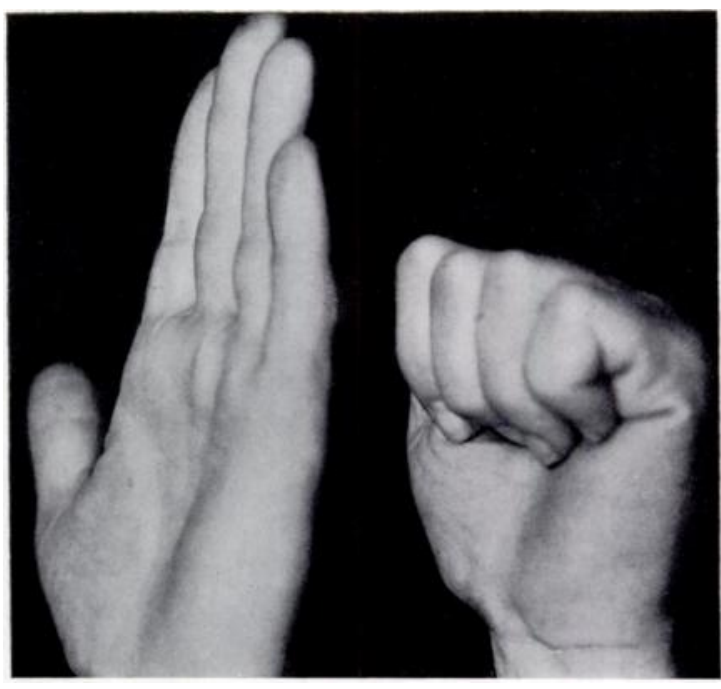

FIG. 10

Case 61. Second degree tendon sheath infection and pulp space infection fourth finger-end-result.

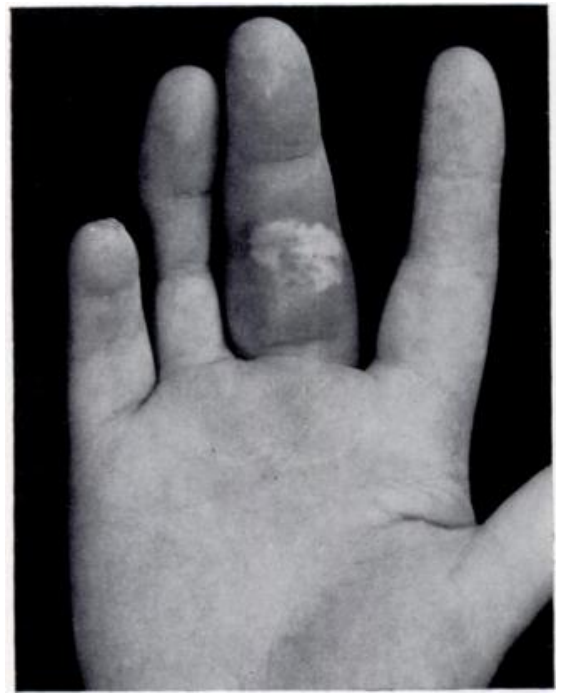

FIG. 11

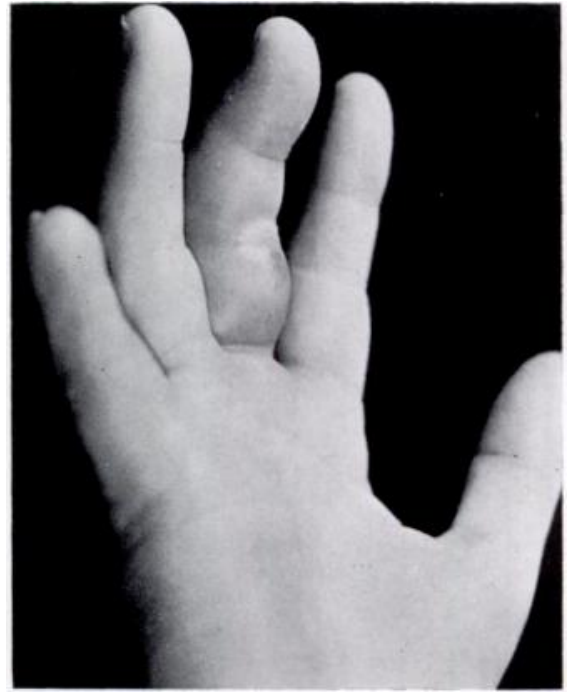

FIG. 12

Case 64. Third degree tendon sheath infection.

by pus. At this stage there is pus formation but no visible evidence of extensive clamage to the sheath or tendon. The sheath is thick, congested, and oedematous; the tendon is swollen but it still retains a glistening appearance. The usual clinical manifestation is a uniformly swollen digit, tender over the whole of the sheath, and with considerable limitation of movement, particularly of extension. There may, however, be definite signs localised to one part 
of the finger when tendon sheath infection arises by lymphatic spread from a pulp space infection in that locality (Case 61, Figs. 9, 10). Treatment should be similar to that described for cases in which there are no localising signs. A skin flap is turned over the area where signs are maximal. All necrotic tissues are thoroughly excised. The sheath is exposed, opened and washed out with saline. Penicillin is instilled from both proximal and distal ends till

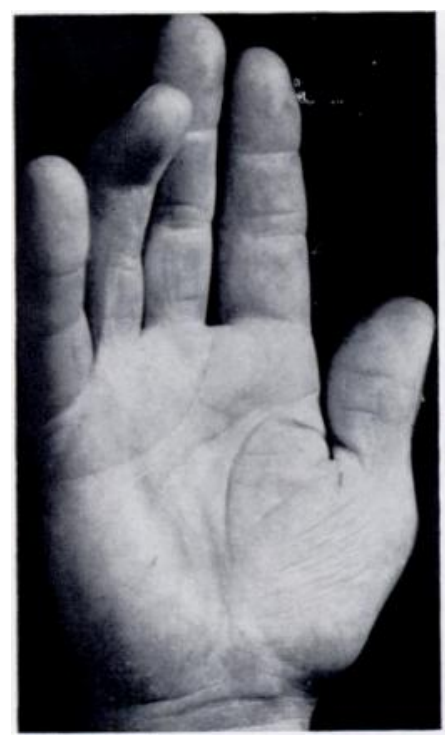

Fig. 13

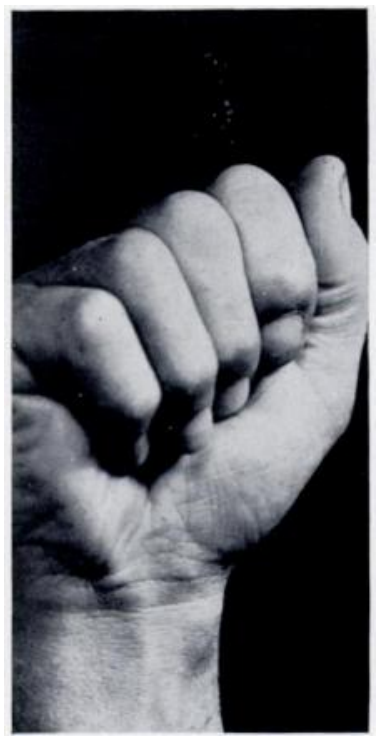

Fig. 14

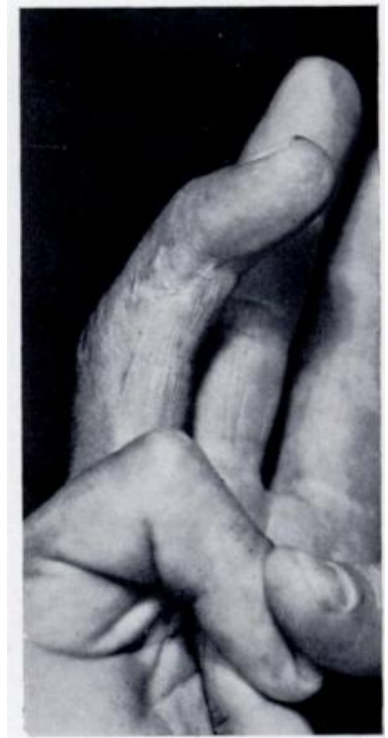

Fig. 15

Case 65. Fourth degree tendon sheath infection with sloughing of tendon, showing the extent of limitation of extension.

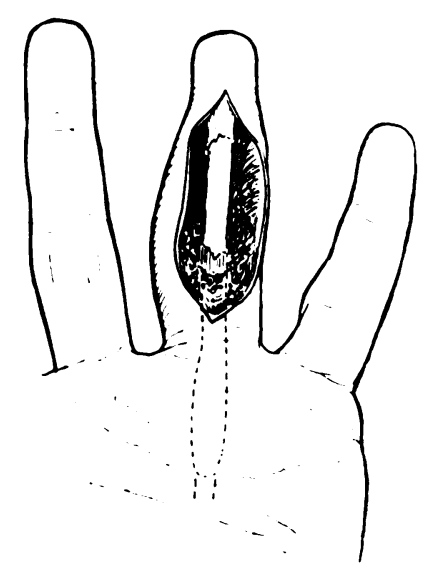

Fig. 16

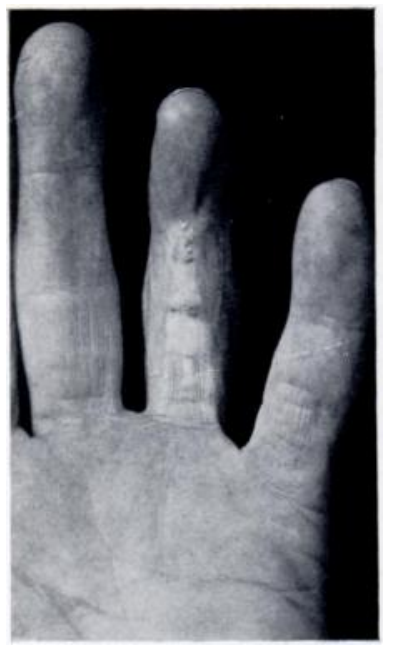

FIG. 17

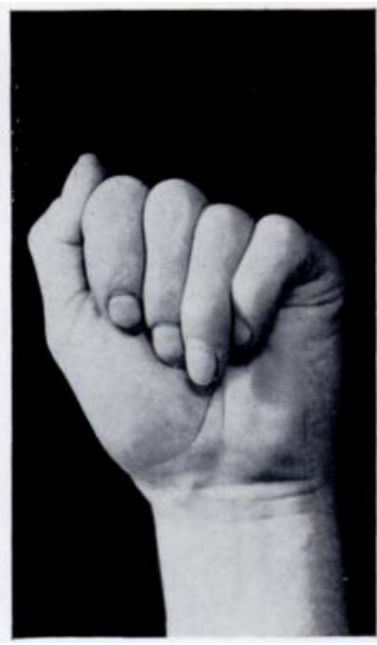

FIG. 18

(ase 66. Fourth degree tendon sheath infection after operation showing late function

clear fluid is obtained. The skin flap is then sutured in the usual manner. Third degree infection is present when part of the sheath has been destroyed, and when there is subcutaneous pus with loss of the normal glistening appearance of the tendon (Case 64, Figs. 11, 1:2). There is redness of the finger, with fluctuation and impaired vitality of skin especially over the palmar surface of one segment. This may be due to fascial space infection caused by direct 
spread from an underlying ruptured sheath, or to fascial space abscess which itself caused the sheath infection. In these cases treatment should follow the lines of a second degree infection with localising signs; excision should include the necrotic areas of the sheath. Fourth degree tendon sheath infection, when a sinus is present, may result from any of the sequences presented above (Cases 65 and 66 , Figs. 13-18). The formation of a sinus, by relief of tension, may be associated with relief of acute symptoms and increase in the range of movement. In one of our cases (Case 65) the diagnosis was confirmed by pressure over the proximal end of the sheath when pus was found to emerge from the sinus. In this type of case the incision should extend through the sinus; careful and thorough excision of all non-riable tissue is carried out, including conservative excision of the sinus edges, cellular tissue, sheath, and tendon. The sheath is washed out, penicillin is instilled, and whenever possible, the skin is sutured in the usual way. If suture is not possible, skin grafting is performed later (Case 66, Figs. 16-18).

With third and fourth degrees of infection there may be necrosis of the tendon due to destruction at the site of the original infection, or to pressure from overlying structures at the flexor creases. As in all other types of infections of the hand, immobilisation in plaster is maintained until healing has occurred and only then are active exercises instituted.

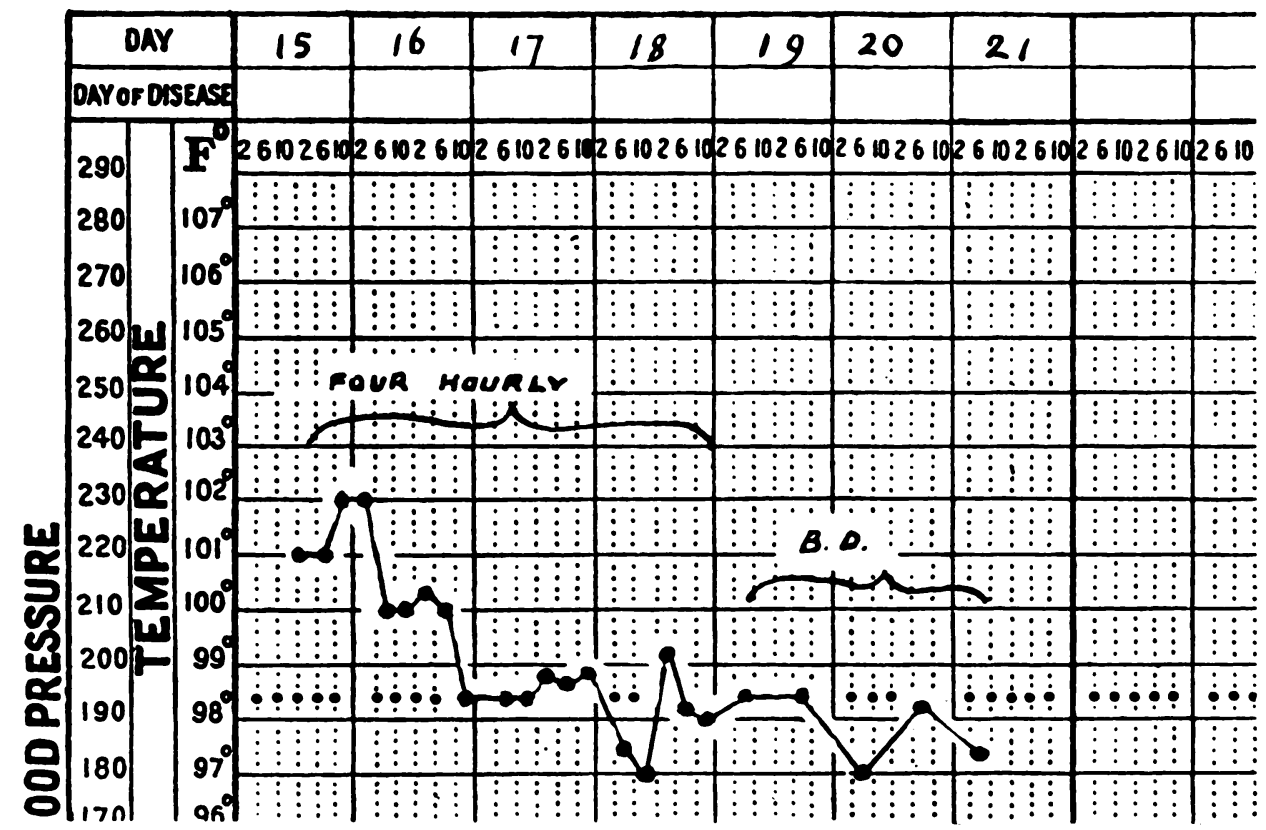

FIG. 19

\section{ILLUSTRATIVE CASES}

Case 3. Fitter, aged 21 years-Signs and symptoms of a second degree distal palmar pulp space infection at the base of the fourth digit of the left hand. He gave a history of having had a " web-space" infection incised and drained in another hospital fourteen days earlier. The scar of the usual incision for a "web-space" infection was well healed but clearly visible. Symptoms had never entirely abated since this operation and were becoming more severe. At operation a two-limbed incision was made (Fig. 2('). A small abscess with thick yellow pus was found directly under the distal palmar pulp: the web-space itself was filled with scar tissue. Excision and suture was carried out. Healing occurred by first intention with complete relief of symptoms.

Comment-From the degree of surrounding fibrous tissue reaction it appeared probable that this abscess was the initial lesion in the original " web-space" infection-the incision for which had succeeded only in draining the space and had left the initial focus of infection to become a residual abscess. 
Case 68. Carrier, aged 52 years-History of a thorn penetrating the radial side of the palm of the left hand. Two days later there were symptoms of acute inflammation and he was treated by his own doctor with poultices and "M. \& B." He was referred to hospital eight days later and admitted as an in-patient on April 15, 1947. He felt ill and had the signs of generalised toxaemia with yellow tint of face and mucosae, furred tongue, and a temperature of 101 degrees Fahrenheit (Fig. 19). There was swelling of the radial side of the palm extending into the thenar region, the dorsum of the hand, and the proximal segment of the index finger. The skin had broken down and an area of acutely tender, soggy, cyanosed skin surrounded a sinus discharging thick grey pus. There was axillary adenitis. The symptoms improved considerably after immobilisation and elevation of the limb, with penicillin 200,000 units initially and 50,000 units three-hourly, and copious fluids. Nevertheless pyrexia continued. Ten hours after admission operation was carried out. All necrotic tissue was removed through an incision designed to excise the sinus. The skin edges were drawn together with loose nylon sutures but it was not possible to secure accurate apposition. April 16, swelling still present; pyrexia up to 100 degrees Fahrenheit; felt well and was free from pain. April 18, swelling practically gone; temperature 99 degrees Fahrenheit. April 19, temperature normal. April 20, elevation discontinued because swelling had disappeared; active exercise of non-immobilised parts encouraged; wound granulating well. April 21, discharged in plaster May 7, pinch grafts applied to the granulating area. Healing occurred by May 13, with full function and good cosmetic result.

Comment-The improvement in general condition after rest, local immobilisation, and chemotherapy was very striking and the use of skin grafts in an area of skin loss undoubtedly hastened healing and the early restoration of function.

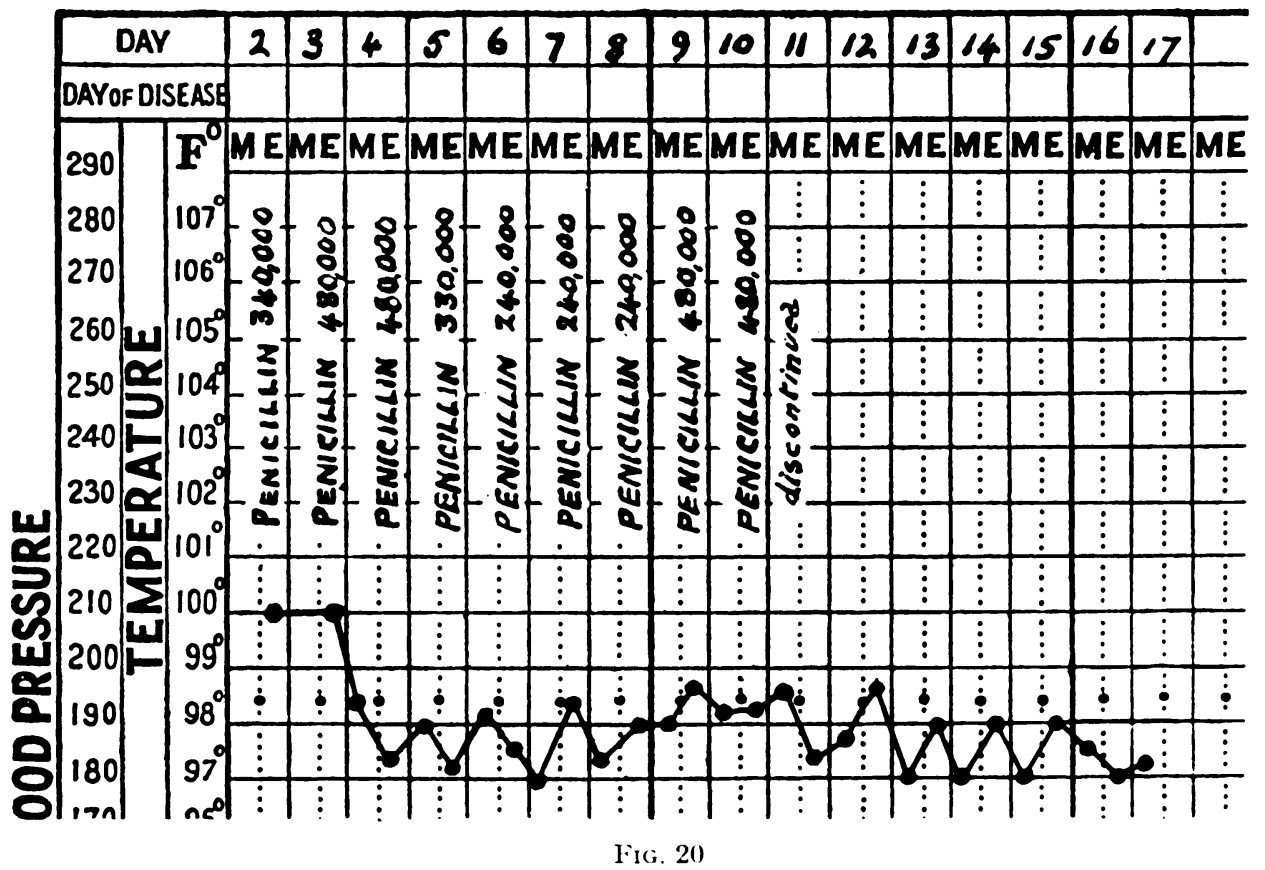

Case 69. Cook, aged 83 years-The patient gave no history of trauma but stated that she woke on the morning of the fourteenth day before admission feeling ill and with a swollen left hani. Twelve hours later the forearm was swollen and red and she complained of pain in the axilla. She was taken to the lecal cottage Hospital and given penicillin therapy. Twelve days later the swelling and redness of the forearm had diminished but there was no improvement in the hand. Incision and drainage of the proximal pulp space of the fifth digit gave no improvement. She was admitted as an in-patient to this hospital, June 2, 1947. General condition was fair with a pyrexia of 100 degrees Fahrenheit (Fig. 20). Locally there was gross swelling of the left hand with obliteration of the normal palmar concavity; swelling of the proximal phalanges of the third, fourth, and fifth digits and of the dorsum of the hand and lower quarter of the forearm, with marked fluctuation just proximal to the flexor retinaculum. There was acute tenderness in all these areas. Novements of the fingers caused pain. There was an enlarged and tender supratrochlear gland. Twelve hours after admission, after general and chemotherapeutic treatment, the hand was explored. The proximal pulp of the fifth digit contained little pus

vol. $30 \mathrm{~B}$, No. 3, August 1948 
but much granulation tissue. In the mid-palmar space communicating with Parona's space there was a considerable quantity of thin yellow pus. This was washed out through two incisions, one as for a mid-palmar space (Fig. 3A), and the other in the line of the proximal flexor skin crease of the wrist curving proximally along the subcutaneous border of ulna. All necrotic tissue was excised. The wound was sutured and the limb immobilised and elevated. June 4, temperature normal; swelling going down; symptom free. June 6, swelling disappeared. June 10, all wounds healed; chemotherapy discontinued and active exercises commenced. June 14, full and painless movements. June 16, discharged from hospital. June 23, returned to work, final cosmetic and functional result perfect.

Case 65. Farm labourer, aged 40 years-Gave a history of having been pricked by a thorn on the right ring finger two weeks before admission; the thorn entered the distal end of the flexor surface of the middle phalanx. One day later there was pain and swelling. Seven days later the finger was incised by his own doctor over the distal end of the middle phalanx. Fourteen days later there had been no improvement despite systemic penicillin and kaolin and magnesium sulphate dressings. He was referred to this unit and admitted as an in-patient on May 31, 1947. Examination showed a finger double the normal size, with an area of skin loss over the middle phalanx covered with granulations. There was swelling. redness and acute tenderness over the proximal phalanx. After immobilisation of the hand and the

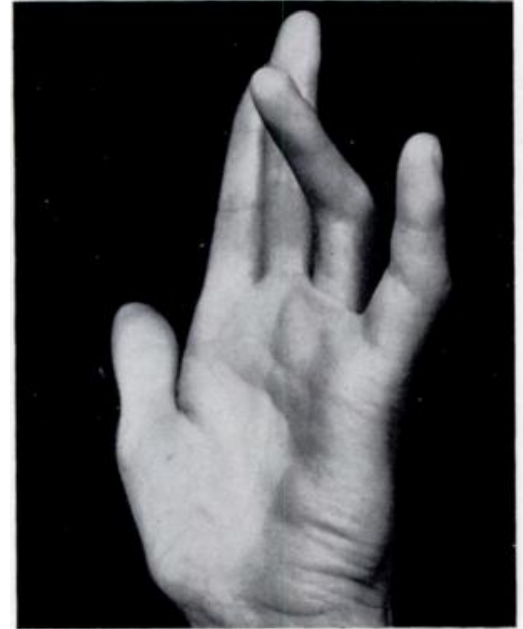

FIG. 21

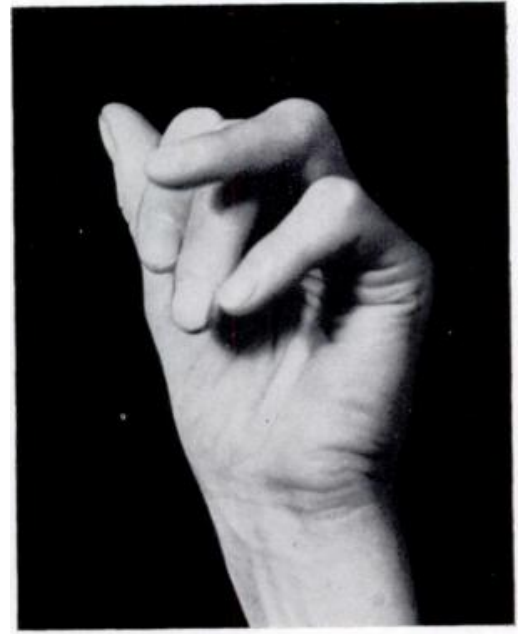

IFIG. 22

(ase 62. Third degree tendon sheath infection showing limited interphalangeal movement.

institution of penicillin therapy-50,000 units three-hourly, operation was carried out under general anaesthesia. The proximal phalanx was explored and an abscess found lying over the opaque and distended tendon sheath. Pressure at this point caused pus to emerge from the wound over the distal flexor crease. All necrotic tissue over the proximal phalanx was excised and the old wound then explored; in this region the tendon sheath had disappeared and the tendon was sloughing. Thorough excision was carried out, including about two-thirds of the width of the tendon. The proximal wound was sutured, the hand immobilised in plaster, and one gramme of sulphadiazine given four-hourly in addition to the penicillin. On June 5 the proximal wound was healed and the distal wound clean and granulating. Ali acute symptoms had subsided. The patient was discharged home. The distal wound healed by secondary intention in a further sixteen days.

Final result -Cosmetically this was good. There was full movement of all joints except the distal interphalangeal joint where there was only 25 degrees of movement and limitation of extension by 35 degrees (Figs. 13-15). This caused no inconvenience and the patient refused physiotherapy on the grounds that the finger was perfectly satisfactory.

Comment-A case of fourth degree tendon sheath infection with necrosis of the tendon and extensive skin loss in which chemotherapy was discontinued on the fifth day after operation because the proximal wound was healed and the distal wound clean and granulating. There seems little doubt that if earlier skin cover had been obtained by skin-grafts, scarring would have been minimised and better function of the distal interphalangeal joint obtained. 
Case 62. Housewife, aged 34 years-Sustained a cut with a nail over the middle pulp of the left fourth digit one week before admission. She had received no treatment other than fomentations. Examination showed the signs of a third degree middle pulp space infection. Had no movement of the finger without pain. At operation the tendon sheath, underlying a pulp abscess, was found to be thickened and opaque; a quantity of pus was washed out of it in the usual manner. Owing to an oversight she was allowed to return home after operation without immobilisation and this was not remedied until two days later (July 7, 1947). A plaster splint was then applied. She was symptom free and remained so until

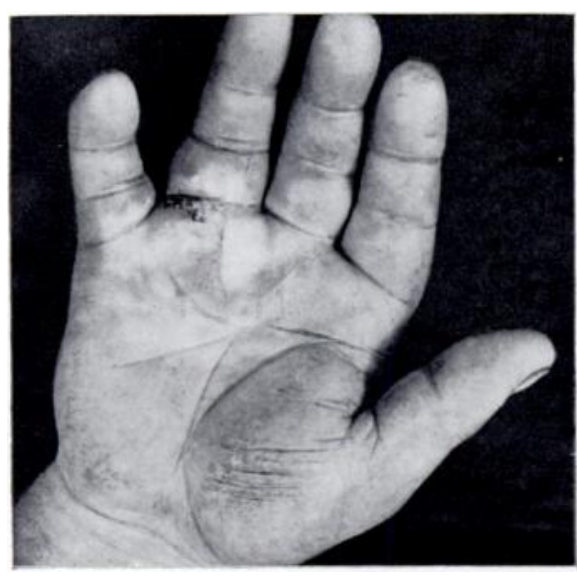

FIG. 23

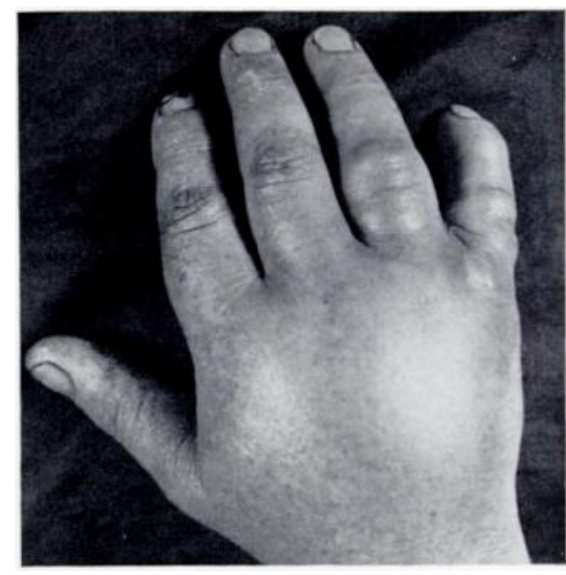

FIG. 24

Case 63. Fourth degree tendon sheath infection, also involving the distal palmar pulp and the mid-palmar space.

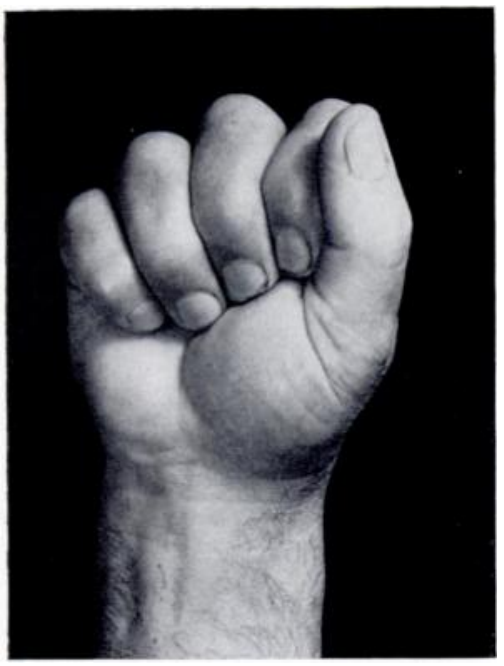

FIG. 25

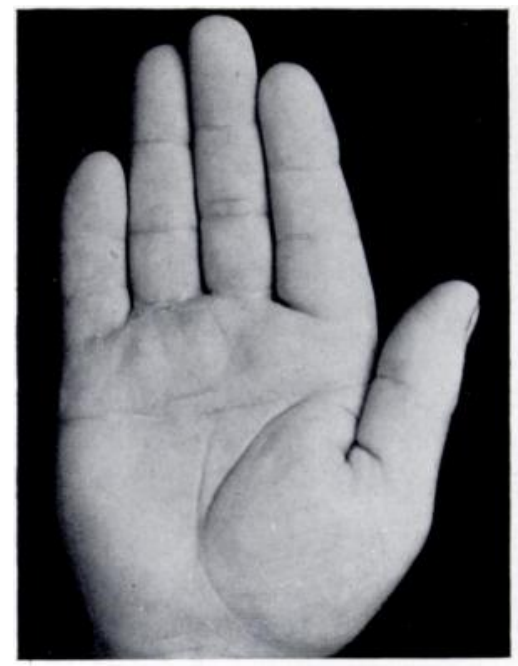

FIG. 26

(ase 63. Showing healing of the wound and function of the finger.

July 12 when removal of the plaster showed that the wound was nearly healed. The plaster was removed and gentle exercises were started. Three days later it was found that the skin flap had sloughed over about half its extent and a small amount of superficial pus overlay granulation tissue. The area was cleaned and penicillin therapy continued; on July 19 the surface was ready for skin-grafting which was carried out with pinch grafts on July 22. The grafts had taken by August 1. By August 17 the cosmetic effect was very good and there was fair movement of the two proximal joints but only about 5 degrees at the distal interphalangeal joint. One month later examination showed that there was very limited movement at the interphalangeal joints (Figs. 21-22).

vol. $30 \mathrm{~B}$, No. 3, AUGUSt 1948 
Case 60. Fishmonger, aged 38 years-Puncture wound with a nail in the distal flexor skin crease of the left index finger, five days before admission. Within twenty-four hours he had increasing pain, swelling and stiffness of the whole finger and was given penicillin 200,000 units daily, together with sulphadiazine by his own doctor, without improvement. He was admitted to this hospital for treatment as an out-patient on July 15, 1947. He complained of marked tenderness and pain on movement in the area shown (Fig. 7) especially on forced extension, but there was fair active flexion-about 20 degrees at each joint. At operation the distal end of the tendon sheath was opened and turbid fluid emerged. The sheath was washed out, the wound sutured, and a plaster splint applied. Penicillin treatment was continued, 200,000 units twice daily, as an out-patient. On July 19 the plaster was removed. The wounds were healed and there were no symptoms or signs of infection. Chemotherapy was discontinued. Active exercises were instituted. By July 25 full function had been regained (Fig. 8).

Case 63. Railway worker, aged 51 years-Cut his right hand seven days before admission. The hand swelled and became painful. He received no treatment until he came to hospital as an out-patient on April 28, 1947. On examination the hand was swollen (Figs. 23-24). All movements of the fingers caused pain, particularly extension of the fourth digit, where there was also tenderness down the line of the tendon sheath. At operation, which was carried out the same day, pus was found in the fourth webspace and the tendon sheath was necrosed. Excision of all necrotic tissue including the sheath was carried out and the sheath was washed through with saline and penicillin from the distal end. Good skin cover was not obtained owing to skin necrosis but approximating sutures were used. He was given penicillin 400,000 units daily in three doses and sulphadiazine 1 gramme four-hourly. On May 2 he was free of symptoms and the swelling had practically gone. The wound was clean and granulating by May 6 . Since good skin cover could not be obtained a full thickness skin graft was applied. By May 15 this had only partly taken but the wound was healed by May 27. Full movements were then quickly obtained by the patient's own active exercise (Figs. 25-26).

Comment-This was the only case where a full thickness skin-graft was used and the result was less satisfactory than after the use of pinch grafts.

Case 64. School teacher, aged 24 years-Developed infection of the proximal pulp space of the right third finger on May 14, 1947. This was treated with penicillin 100,000 units twice daily but deterioration took place. She came to hospital on May 19 and presented the picture shown (Figs. 11 and 12). Active movements of the finger were possible but limited; passive extension caused pain. There was tenderness over the line of the tendon sheath and the skin was devitalised and necrotic round a sinus. At operation pus was found in the tendon sheath and in the pulp space. The usual procedure was carried out, including excision of the sinus edges. Healing occurred in eight days with full and painless movement of the finger.

\section{DISCUSSION}

An attempt has been made to outline the rationale of an approach to the treatment of infections of the hand, which in some respects is new. The paper is in the nature of a preliminary report. Conclusions based on a series of only sixty-nine consecutive cases must obviously be tentative. It may be learnt from Tables I and II that thirty-eight cases without skin necrosis healed in an average time of $\mathbf{7 \cdot 3}$ days; while the other thirty-one cases, with some degree of skin loss, healed in an average of $\mathbf{1 9 \cdot 6}$ days. These figures serve to emphasize once more the importance of early diagnosis and treatment. Of these sixty-nine cases, $\mathbf{5 5}$ per cent. had already received various forms of treatment before being sent to hospital, including penicillin and sulphadiazine therapy; and of these, 29 per cent. had received surgical treatment elsewhere. It seems clear that two further points require emphasis: 1) chemotherapy alone, except perhaps in the very early stages of infection, does not influence the local lesion; 2) surgical treatment must be radical at whatever stage it is employed.

In these tables the time of healing was calculated in days from the date of operation to the date when healing was complete. When more than one operation was performed-as in the case of skin grafting after excision-the time of healing was calculated from the date of the first operation. Our criterion of healing was complete healing of the wound without surface moisture, granulation tissue, or scab. In all cases, except those where the functional result was imperfect (two in number), patients were able to return to work as soon as the 
TABIEE I

\begin{tabular}{|c|c|c|c|c|c|c|c|c|}
\hline \multicolumn{5}{|c|}{ Distal Palmar } & \multicolumn{2}{|c|}{ Pulp Space (Web Space) } & \multicolumn{2}{|l|}{ INFECTIONS } \\
\hline $\begin{array}{l}\text { Case } \\
\text { No. }\end{array}$ & Sex & Age & Occupation & Degree & $\begin{array}{l}\text { Length of } \\
\text { history } \\
\text { in days }\end{array}$ & $\begin{array}{l}\text { Previous } \\
\text { treatment }\end{array}$ & Remarks & $\begin{array}{l}\text { Time of } \\
\text { healing } \\
\text { in days }\end{array}$ \\
\hline 1 & $\mathbf{M}$ & 20 & Student & 2 & 2 & None & Following rowing blister & 9 \\
\hline 2 & $\mathbf{M}$ & 27 & Lorry driver & 2 & 3 & None & Blister & 9 \\
\hline 3 & $\mathbf{M}$ & 21 & Fitter & 2 & 14 & $\begin{array}{l}\text { Kaolin, } \\
\text { incision }\end{array}$ & $\begin{array}{l}\text { Incised as web space else- } \\
\text { where. Residual abscess } \\
\text { in distal palmar pulp. }\end{array}$ & 7 \\
\hline 4 & M. & 45 & Fitter & 2 & 5 & Penicillin & Blister & 4 \\
\hline 5 & $\mathbf{M}$. & 15 & College servant & 2 & 5 & Penicillin & - & 8 \\
\hline 6 & M. & 6 & Schoolboy & 2 & 3 & None & Blister & 4 \\
\hline 7 & M. & 37 & Steelworker & 3 & 7 & Poultices & Blister & 5 \\
\hline 8 & $\mathbf{M}$. & 24 & Groundsman & 3 & 7 & None & - & 9 \\
\hline 9 & $\mathbf{M}$. & 13 & Schoolboy & 3 & 2 & None & - & 6 \\
\hline 10 & M. & 6 & Schoolboy & 3 & ? & Poultices & Blister & 8 \\
\hline & & & & & Thenar Sp & ACE INFECTIONS & & \\
\hline 11 & $\mathbf{M}$ & 24 & Engineer & 2 & 6 & Sulphonamides & $\begin{array}{l}\text { Similar infection in same } \\
\text { locality } 6 \text { months earlier } \\
\text { treated by incision and } \\
\text { drainage }\end{array}$ & 8 \\
\hline 12 & $\mathrm{~F}$. & 38 & Housewife & 2 & 3 & Poultices & 一 & 6 \\
\hline 13 & $\mathrm{~F}$. & 43 & Housewife & 3 & 3 & Penicillin & 一 & 10 \\
\hline 14 & M. & 41 & Vanman & 4 & $?$ & Penicillin & 一 & 12 \\
\hline 15 & $\mathrm{I}$ & 57 & Needlewoman & 4 & 2 & None & $\begin{array}{l}\text { Treated with sulpha- } \\
\text { diazine only for } 4 \text { days } \\
\text { post-operatively but } \\
\text { without penicillin }\end{array}$ & 6 \\
\hline 16 & $\mathrm{~F}$ & 61 & Housewife & 4 & 42 & $\begin{array}{c}\text { Penicillin, } \\
\text { incision and } \\
\text { drainage else- } \\
\text { where }\end{array}$ & In-patient for 5 days & 12 \\
\hline \multicolumn{9}{|c|}{ Mid-Palmar Space Infections } \\
\hline 17 & $\mathbf{M}$ & 20 & Student & 2 & 4 & None & $\begin{array}{l}\text { Rowing blister. Subse- } \\
\text { quently rowed before } \\
\text { removal of sutures }\end{array}$ & 5 \\
\hline 18 & $\mathbf{M}$. & 51 & Furnaceman & 3 & 25 & $\begin{array}{l}\text { Penicillin, } \\
\text { incision and } \\
\text { drainage else- } \\
\text { where }\end{array}$ & $\begin{array}{l}\text { Wound of previous } \\
\text { operation unhealed }\end{array}$ & 11 \\
\hline
\end{tabular}


J. B. LOUDON, J. D. MINIERO, AND J. C. SCOTT

TABLE I-continued

\begin{tabular}{|c|c|c|c|c|c|c|c|c|}
\hline \multicolumn{9}{|c|}{ Dorsal Space Infections } \\
\hline $\begin{array}{l}\text { Case } \\
\text { No. }\end{array}$ & $\operatorname{Sex}$ & Age & Occupation & Degree & $\begin{array}{l}\text { Length of } \\
\text { history } \\
\text { in days }\end{array}$ & $\begin{array}{l}\text { Previous } \\
\text { treatment }\end{array}$ & Remarks & $\begin{array}{l}\text { Time of } \\
\text { healing } \\
\text { in days }\end{array}$ \\
\hline 19 & M. & 19 & Gardener & 2 & 3 & $\begin{array}{l}\text { Penicillin, } \\
\text { Sulphadiazine }\end{array}$ & $\begin{array}{l}\text { No post-operative } \\
\text { chemotherapy }\end{array}$ & 7 \\
\hline 20 & M. & 23 & Steelworker & 3 & 5 & $\begin{array}{l}\text { Penicillin, } \\
\text { Kaolin }\end{array}$ & $\begin{array}{l}\text { ? Due to an insect } \\
\text { bite }\end{array}$ & 7 \\
\hline \multicolumn{9}{|c|}{ Proximal Pulp Spaces } \\
\hline 21 & M. & 14 & None & 2 & 5 & "Soaks" & - & 10 \\
\hline 22 & M. & 30 & Driver & 2 & 3 & None & - & 6 \\
\hline 23 & F. & 15 & Domestic & 2 & 4 & None & $\begin{array}{l}\text { No chemotherapy either } \\
\text { pre- or post-operatively }\end{array}$ & 7 \\
\hline 24 & $\mathrm{~F}$. & 15 & None & 3 & 7 & None & - & 7 \\
\hline 25 & M. & 16 & Student & 3 & 5 & None & - & 10 \\
\hline 26 & M. & 20 & Student & 3 & 5 & Penicillin & $\begin{array}{l}\text { Rowing blister. Lymph- } \\
\text { angitis and adenitis on } \\
\text { admission }\end{array}$ & 8 \\
\hline 27 & M. & 25 & Electrician & 3 & 6 & None & $\begin{array}{l}\text { Also had accompanying } \\
\text { paronychia which healed } \\
\text { in } 7 \text { days. Chemotherapy } \\
\text { - Penicillin for } 2 \text { days } \\
\text { followed by sulphadiazine } \\
\text { for } 3 \text { days }\end{array}$ & 18 \\
\hline 28 & $\mathbf{M}$ & 43 & Printer & 4 & 4 & $\begin{array}{l}\text { Penicillin, } \\
\text { incision and } \\
\text { drainage else- } \\
\text { where }\end{array}$ & $\begin{array}{l}\text { Discharging sinus after } \\
\text { first operation not } \\
\text { excised: plaster removed } \\
\text { on 4th day and exercises } \\
\text { started }\end{array}$ & 43 \\
\hline 29 & M. & 18 & $\begin{array}{l}\text { Canteen } \\
\text { worker }\end{array}$ & 4 & 4 & None & $\begin{array}{l}\text { Discharging sinus excised. } \\
\text { Compare with Case } 28\end{array}$ & 5 \\
\hline \multicolumn{9}{|c|}{ Middle PUlp Space Infections } \\
\hline 30 & M. & 14 & $\begin{array}{l}\text { Farm } \\
\text { labourer }\end{array}$ & 2 & 8 & None & - & 7 \\
\hline 31 & M. & 19 & $\begin{array}{l}\text { Factory } \\
\text { worker }\end{array}$ & 2 & 3 & None & - & 7 \\
\hline 32 & $\mathrm{~F}$. & 30 & Housewife & 3 & $\mathbf{5}$ & None & $\begin{array}{l}\text { Removed own dressing on } \\
\text { 2nd day. No immobilisa- } \\
\text { tion. Skin graft on 14th } \\
\text { day }\end{array}$ & 32 \\
\hline 33 & M. & 34 & $\begin{array}{l}\text { Transport } \\
\text { manager }\end{array}$ & 3 & 7 & None & Skin graft on 6th day & 30 \\
\hline 34 & M. & 26 & Plumber & 3 & 3 & None & - & 16 \\
\hline 35 & M. & 23 & Student & 3 & 7 & None & $\begin{array}{l}\text { Rowing blister. Subse- } \\
\text { quently rowed before } \\
\text { removal of sutures }\end{array}$ & 9 \\
\hline
\end{tabular}


TABLE I-continued

Distal Pulp Space Infections

\begin{tabular}{|c|c|c|c|c|c|c|c|c|}
\hline $\begin{array}{c}\text { Case } \\
\text { No. }\end{array}$ & Sex & Age & Occupation & Degree & $\begin{array}{l}\text { Length of } \\
\text { history } \\
\text { in days }\end{array}$ & $\begin{array}{l}\text { Previous } \\
\text { treatment }\end{array}$ & Remarks & $\begin{array}{l}\text { Time of } \\
\text { healing } \\
\text { in days }\end{array}$ \\
\hline 36 & F. & 17 & Nurse & 2 & 2 & Poultice & - & 4 \\
\hline 37 & F. & 32 & Housewife & 2 & 21 & None & - & 5 \\
\hline 38 & F. & 15 & None & 2 & 2 & None & $\begin{array}{l}\text { No chemotherapy either } \\
\text { pre- or post-operatively }\end{array}$ & 5 \\
\hline 39 & M. & 38 & $\begin{array}{l}\text { Motor } \\
\text { mechanic }\end{array}$ & 2 & 6 & Penicillin & - & 10 \\
\hline 40 & F. & 5 & None & 3 & 2 & None & - & 9 \\
\hline 41 & F. & 48 & Housewife & 3 & 10 & Kaolin & - & 19 \\
\hline 42 & F. & 15 & Domestic & 3 & 5 & $\begin{array}{l}\text { Penicillin, } \\
\text { Kaolin }\end{array}$ & - & 7 \\
\hline 43 & M. & 22 & Woodworker & 3 & 2 & None & - & 12 \\
\hline 44 & F. & 16 & Domestic & 4 & 7 & Poultices & Poor cosmetic result & 11 \\
\hline 45 & M. & 25 & Student & 4 & 8 & $\begin{array}{l}\text { Incision and } \\
\text { drainage else- } \\
\text { where }\end{array}$ & - & 7 \\
\hline 46 & F. & 27 & Housewife & 4 & 2 & $\begin{array}{l}\text { Sulphonamides, } \\
\text { incision and } \\
\text { drainage else- } \\
\text { where }\end{array}$ & - & 3 \\
\hline
\end{tabular}

Dorsal Space (Finger) Infection

\begin{tabular}{|l|l|l|l|l|l|l|l|l}
\hline 47 & M. & 44 & $\begin{array}{c}\text { Farm } \\
\text { labourer }\end{array}$ & 4 & 21 & Poultices & Extensive skin loss & 21 \\
\hline
\end{tabular}

Paronychiae

\begin{tabular}{|c|c|c|c|c|c|c|c|c|}
\hline 48 & M. & 25 & Electrician & 2 & 6 & None & $\begin{array}{l}\text { Also had proximal pulp } \\
\text { space (see Case 27) }\end{array}$ & 7 \\
\hline 49 & F. & 29 & Housewife & 2 & 4 & Kaolin & 一 & 5 \\
\hline 50 & F. & 20 & Domestic & 3 & ? & $\begin{array}{l}\text { Penicillin, } \\
\text { Kaolin }\end{array}$ & $\begin{array}{l}\text { Culture of pus showed } \\
\text { haemolytic streptococcus } \\
\text { in addition to the usual } \\
\text { staphylococcus aureus }\end{array}$ & 8 \\
\hline 51 & F. & 65 & Domestic & 3 & 7 & None & - & 4 \\
\hline 52 & $\mathrm{~F}$. & 40 & Housewife & 3 & 2 & None & 一 & 6 \\
\hline 53 & M. & 47 & $\begin{array}{c}\text { Antique } \\
\text { dealer }\end{array}$ & 3 & 6 & None & $\begin{array}{l}\text { Also had proximal pulp } \\
\text { space infections }\end{array}$ & 8 \\
\hline
\end{tabular}

vol. $30 \mathrm{~B}$, No. 3 , AUgust 1948 
TABLE, I-continued

\begin{tabular}{|c|c|c|c|c|c|c|c|c|}
\hline \multicolumn{9}{|c|}{ Pulp Space (Finger) Infections With Osteitis } \\
\hline $\begin{array}{l}\text { Case } \\
\text { No. }\end{array}$ & Sex & Age & Occupation & Degree & $\begin{array}{l}\text { Length of } \\
\text { history } \\
\text { in days }\end{array}$ & $\begin{array}{l}\text { Previous } \\
\text { treatment }\end{array}$ & Remarks & $\begin{array}{l}\text { Time of } \\
\text { healing } \\
\text { in days }\end{array}$ \\
\hline 54 & $\mathrm{~F}$. & 39 & Housewife & $\begin{array}{c}4 \\
\text { with } \\
\text { osteitis }\end{array}$ & 21 & $\begin{array}{l}\text { Sulphonamides, } \\
\text { Penicillin. Two } \\
\text { operations for } \\
\text { incision and } \\
\text { drainage else- } \\
\text { where }\end{array}$ & $\begin{array}{l}\text { Sequestrectomy carried } \\
\text { out through shark-mouth } \\
\text { incision, excising sinus. } \\
\text { Suture. Final cosmetic } \\
\text { result fair }\end{array}$ & 10 \\
\hline 55 & F. & 43 & Housewife & $\begin{array}{c}4 \\
\text { with } \\
\text { osteitis }\end{array}$ & 21 & $\begin{array}{l}\text { Penicillin, } \\
\text { Sulphonamides, } \\
\text { Kaolin, } \\
\text { incision and } \\
\text { drainage }\end{array}$ & $\begin{array}{l}\text { Sequestrectomy and } \\
\text { suture. Final cosmetic } \\
\text { result good }\end{array}$ & 16 \\
\hline 56 & M. & 27 & $\begin{array}{l}\text { Metal } \\
\text { worker }\end{array}$ & $\begin{array}{c}4 \\
\text { with } \\
\text { osteitis }\end{array}$ & 7 & $\begin{array}{l}\text { Sulphonamides, } \\
\text { Kaolin }\end{array}$ & $\begin{array}{l}\text { Terminal pulp a " bag of } \\
\text { pus" on admission }\end{array}$ & 15 \\
\hline 57 & M. & 65 & Licensee & $\begin{array}{c}4 \\
\text { with } \\
\text { osteitis }\end{array}$ & 180 & $\begin{array}{l}\text { Incision } \\
\text { and drainage } \\
\text { elsewhere. } \\
\text { Dressings }\end{array}$ & $\begin{array}{l}\text { Sequestrectomy and } \\
\text { suture. Final cosmetic } \\
\text { result good }\end{array}$ & 10 \\
\hline 58 & F. & 50 & Housewife & $\begin{array}{c}4 \\
\text { with } \\
\text { osteitis }\end{array}$ & 42 & "Soaks" & $\begin{array}{l}\text { Sequestrectomy and } \\
\text { suture. Final cosmetic } \\
\text { result good }\end{array}$ & 8 \\
\hline 59 & F. & 47 & Housewife & $\begin{array}{c}4 \\
\text { with } \\
\text { osteitis }\end{array}$ & 6 & None & $\begin{array}{c}\text { Skin graft failed. Osteitis } \\
\text { amputation of terminal } \\
\text { phalanx }\end{array}$ & 68 \\
\hline \multicolumn{9}{|c|}{ Tendon Sheath Infections } \\
\hline 60 & M. & 38 & Fishmonger & 1 & 7 & $\begin{array}{l}\text { Penicillin, } \\
\text { Sulphonamides }\end{array}$ & $\begin{array}{l}\text { Puncture wound in distal } \\
\text { flexor crease index finger } \\
\text { culture - staphylococcus } \\
\text { aureus. Full painless } \\
\text { movements in } 14 \text { days }\end{array}$ & 9 \\
\hline 61 & F. & 38 & Housewife & 2 & 4 & Sulphonamides & $\begin{array}{l}\text { Also had 2nd degree } \\
\text { proximal, and 4th degree } \\
\text { distal pulp space infec- } \\
\text { tion. Pus in the tendon } \\
\text { sheath but sheath intact. } \\
\text { Culture-pus cells. Full } \\
\text { painless movements in } 14 \\
\text { days }\end{array}$ & 7 \\
\hline 62 & F. & 34 & Housewife & 3 & 4 & None & $\begin{array}{l}\text { Also had 3rd degree } \\
\text { middle pulp space in- } \\
\text { fection. Skin graft after } \\
\text { break-down of skin over } \\
\text { proximal pulp. Cosmetic } \\
\text { result good. Functional } \\
\text { result poor. }\end{array}$ & 36 \\
\hline
\end{tabular}


TABLE I-continued

\begin{tabular}{|c|c|c|c|c|c|c|c|c|}
\hline \multicolumn{9}{|c|}{ TEndon Sheath Infections-continued } \\
\hline $\begin{array}{l}\text { Case } \\
\text { No. }\end{array}$ & $\operatorname{Sex}$ & Age & Occupation & Degree & $\begin{array}{l}\text { Length of } \\
\text { history } \\
\text { in days }\end{array}$ & $\begin{array}{l}\text { Previous } \\
\text { treatment }\end{array}$ & Remarks & $\begin{array}{l}\text { Time of } \\
\text { healing } \\
\text { in days }\end{array}$ \\
\hline 63 & M. & 51 & $\begin{array}{l}\text { Railway } \\
\text { worker }\end{array}$ & 4 & 7 & None & $\begin{array}{c}\text { Also had 4th degree distal } \\
\text { palmar pulp which spread } \\
\text { to mid-palmar space and } \\
\text { tendon sheath. Culture- } \\
\text { staphylococcus aureus. } \\
\text { Functional and cosmetic } \\
\text { result good }\end{array}$ & 29 \\
\hline 64 & F. & 24 & $\begin{array}{l}\text { School } \\
\text { teacher }\end{array}$ & 4 & 5 & $\begin{array}{l}\text { Penicillin } \\
100,000 \text { units } \\
\text { for } 3 \text { days }\end{array}$ & $\begin{array}{l}\text { Also had proximal pulp } \\
\text { abscess } 4 \text { th degree. } \\
\text { Culture - staphylococcus } \\
\text { aureus. Cosmetic and } \\
\text { functional result good }\end{array}$ & 8 \\
\hline 65 & M. & 40 & $\begin{array}{c}\text { Farm } \\
\text { labourer }\end{array}$ & $\begin{array}{c}4 \\
\text { with } \\
\text { slough- } \\
\text { ing } \\
\text { tendon }\end{array}$ & $14 \bullet$ & $\begin{array}{c}\text { Penicillin, } \\
\text { incision and } \\
\text { drainage else- } \\
\text { where }\end{array}$ & $\begin{array}{l}\text { Puncture wound. Also had } \\
\text { 4th degree proximal pulp } \\
\text { abscess. Tendon sloughing } \\
\text { under distal flexor crease. } \\
\text { Culture - staphylococcus } \\
\text { aureus. In-patient for } 5 \\
\text { days. Functional result } \\
\text { good except for limitation } \\
\text { of extension of the } \\
\text { terminal IP joint by } 20 \\
\text { degrees. Cosmetic result } \\
\text { good }\end{array}$ & 21 \\
\hline 66 & M. & 37 & $\begin{array}{l}\text { Motor } \\
\text { mechanic }\end{array}$ & $\begin{array}{c}4 \\
\text { with } \\
\text { extensive } \\
\text { skin } \\
\text { loss }\end{array}$ & 3 & $\begin{array}{c}\text { Incision and } \\
\text { drainage else- } \\
\text { where }\end{array}$ & $\begin{array}{l}\text { Tendon sheath sloughed } \\
\text { skin graft on 6th day. } \\
\text { Final cosmetic and } \\
\text { functional result good }\end{array}$ & 36 \\
\hline \multicolumn{9}{|c|}{ Multiple Lesions } \\
\hline 67 & $\mathbf{M}$ & 51 & $\begin{array}{l}\text { Railway } \\
\text { worker }\end{array}$ & 3 & 7 & None & $\begin{array}{l}\text { Distal palmar pulp +mid- } \\
\text { palmar space }+ \text { tendon } \\
\text { sheath infections. (See } \\
\text { Case 63) }\end{array}$ & 29 \\
\hline 68 & M. & 52 & Carrier & $\begin{array}{c}4 \\
\text { with } \\
\text { extensive } \\
\text { skin } \\
\text { loss }\end{array}$ & 5 & Sulphonamides & $\begin{array}{l}\text { Dorsal subaponeurotic } \\
\text { space of hand and proxi- } \\
\text { mal phalanx of index } \\
\text { finger t thenar space. Skin } \\
\text { graft on 22nd day. Healed } \\
6 \text { days later }\end{array}$ & 28 \\
\hline 69 & F. & 83 & Cook & 4 & 14 & $\begin{array}{c}\text { Penicillin, } \\
\text { incision and } \\
\text { drainage else- } \\
\text { where }\end{array}$ & $\begin{array}{l}\text { Spreading infection from } \\
\text { proximal pulp 5th finger } \\
\text { into mid-palmar and } \\
\text { Parona's spaces. In - } \\
\text { patient treatment }\end{array}$ & 8 \\
\hline
\end{tabular}

vol. $30 \mathrm{~B}$, No. 3, AUgust 1948 
wound was healed, and in many cases work was carried on even while there was immobilisation in plaster.

No contemporary control series was attempted, but a comparison may justifiably be made with those cases which attended the Casualty Department of this hospital in the six months immediately before the period covered by this survey. These cases had similar treatment by penicillin and sulphadiazine; they were treated as in-patients when necessary; and they came under the care of the same Accident Service which carried out the work reported in this paper. During this earlier period, however, surgical treatment was of the orthodox type, with the usual methods of incision and drainage. The average time of healing for these cases was $\mathbf{1 9 . 3}$ days, contrasted with $12 \cdot 7$ days for the present series.

TABLE II

\begin{tabular}{|c|c|c|c|c|c|c|c|c|}
\hline \multirow[b]{2}{*}{ Type of infection } & \multirow[b]{2}{*}{ 岁总 } & \multirow{2}{*}{ 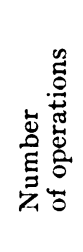 } & \multirow{2}{*}{ 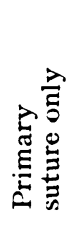 } & \multirow[b]{2}{*}{ 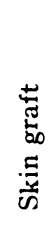 } & \multirow{2}{*}{ 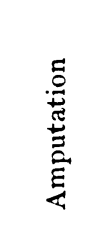 } & \multirow{2}{*}{ 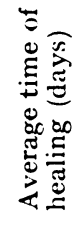 } & \multicolumn{2}{|c|}{ Final result } \\
\hline & & & & & & & 吾 & 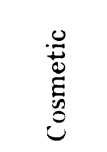 \\
\hline Distal palmar pulp space & 10 & 10 & 10 & 0 & 0 & $6 \cdot 9$ & Full & Good \\
\hline Thenar space . . & 6 & 6 & 6 & 0 & 0 & 9 & Full & Good \\
\hline Mid-palmar space $\quad$. & 2 & 2 & 2 & 0 & 0 & 8 & Full & Good \\
\hline Dorsal space $\quad \cdot \quad$. & 2 & 2 & 2 & 0 & 0 & 7 & Full & Good \\
\hline $\begin{array}{l}\text { Proximal pulp space: } \\
1 \text { st and 2nd degree } \\
\text { 3rd and 4th degree. }\end{array}$ & $\begin{array}{l}3 \\
6\end{array}$ & $\begin{array}{l}3 \\
6\end{array}$ & $\begin{array}{l}3 \\
6\end{array}$ & $\begin{array}{l}0 \\
0\end{array}$ & $\begin{array}{l}0 \\
0\end{array}$ & $\begin{array}{r}7 \cdot 6 \\
15 \cdot 1\end{array}$ & $\begin{array}{l}\text { Full } \\
\text { Full }\end{array}$ & $\begin{array}{l}\text { Good } \\
\text { Good }\end{array}$ \\
\hline $\begin{array}{l}\text { Middle pulp space: } \\
\text { 1st and 2nd degree. } \\
\text { 3rd and 4th degree. }\end{array}$ & $\begin{array}{l}2 \\
4\end{array}$ & $\begin{array}{l}2 \\
6\end{array}$ & $\begin{array}{l}2 \\
2\end{array}$ & $\begin{array}{l}0 \\
2\end{array}$ & $\begin{array}{l}0 \\
0\end{array}$ & $\begin{array}{c}7 \\
21.7\end{array}$ & $\begin{array}{l}\text { Full } \\
\text { Full }\end{array}$ & $\begin{array}{l}\text { Good } \\
\text { Good }\end{array}$ \\
\hline $\begin{array}{l}\text { Distal pulp space: } \\
\text { 1st and 2nd degree. } \\
\text { 3rd and 4th degree. }\end{array}$ & $\begin{array}{l}4 \\
7\end{array}$ & $\begin{array}{l}4 \\
7\end{array}$ & $\begin{array}{l}4 \\
7\end{array}$ & $\begin{array}{l}0 \\
0\end{array}$ & $\begin{array}{l}0 \\
0\end{array}$ & $\begin{array}{l}6 \\
9 \cdot 7\end{array}$ & $\begin{array}{l}\text { Full } \\
\text { Full }\end{array}$ & $\begin{array}{l}\text { Good } \\
\text { Good }\end{array}$ \\
\hline Dorsal space (finger) . & 1 & 1 & 1 & 0 & 0 & 21 & Full & Good \\
\hline Paronychia . . . & 6 & 6 & 6 & 0 & 0 & $6 \cdot 3$ & Full & Good \\
\hline $\begin{array}{l}\text { Pulp space (finger): } \\
\text { 3rd and 4th degree with } \\
\text { osteitis. }\end{array}$ & 6 & 8 & 5 & 1 & $\begin{array}{l}\text { One } \\
\text { term: } \\
\text { phalanx }\end{array}$ & $21 \cdot 1$ & Full & $\begin{array}{l}5 \text { Good } \\
1 \text { Fair }\end{array}$ \\
\hline $\begin{array}{l}\text { Tendon sheath: } \\
\text { 1st and 2nd degree. } \\
\text { 3rd and 4th degree }\end{array}$ & $\begin{array}{l}2 \\
5\end{array}$ & $\begin{array}{l}2 \\
9\end{array}$ & $\begin{array}{l}2 \\
1\end{array}$ & $\begin{array}{l}0 \\
4\end{array}$ & $\begin{array}{l}0 \\
0\end{array}$ & $\begin{array}{r}8 \\
26\end{array}$ & $\begin{array}{c}\text { Full } \\
\left\{\begin{array}{l}\text { Full } 3 \\
\text { Poor } 2\end{array}\right.\end{array}$ & $\begin{array}{l}\text { Good } \\
\text { Good }\end{array}$ \\
\hline Multiple lesions & 3 & 5 & 1 & 2 & 0 & $21 \cdot 6$ & Full & Good \\
\hline Total . . . & 69 & 79 & 60 & 9 & 1 & $12 \cdot 7$ & 一 & - \\
\hline
\end{tabular}

Florey and Williams (1944), and Curr (1945), investigated two series from the point of view of penicillin therapy. Their results, where comparable in other respects with ours, are shown in Table III. These workers used local and systemic penicillin combined with surgical intervention. 
Warning as to possible dangers of the proposed treatment-Certain features of the treatment which has been described are not without danger. The operative procedure is prolonged. All the facilities described are essential if it is to be executed properly. Wide exposure increases the possibility of damage to important structures, particularly if it is carried out by inexperienced surgeons.

The possibility of recurrence of local infection after excision, primary suture, and the application of a plaster splint, was considered at the beginning to be the main danger; but it transpired that this was not so. Only those patients who required skin grafts needed more than one operation.

TABLE III

Time of Healing in Three Series of Hand Infections

\begin{tabular}{|c|c|c|c|c|c|c|}
\hline & \multicolumn{2}{|c|}{ Present Series } & \multicolumn{2}{|c|}{ Florey and Williams } & \multicolumn{2}{|c|}{ Curr } \\
\hline & $\begin{array}{l}\text { Number } \\
\text { of cases }\end{array}$ & $\begin{array}{l}\text { Days in } \\
\text { healing }\end{array}$ & $\begin{array}{l}\text { Number } \\
\text { of cases }\end{array}$ & $\begin{array}{l}\text { Days in } \\
\text { healing }\end{array}$ & $\begin{array}{l}\text { Number } \\
\text { of cases }\end{array}$ & $\begin{array}{l}\text { Days in } \\
\text { healing }\end{array}$ \\
\hline Pulp space infections & 26 & $11 \cdot 8$ & 22 & $21 \cdot 7$ & 18 & 23 \\
\hline Distal palmar pulp infections. & 10 & $6 \cdot 9$ & 9 & $18 \cdot 8$ & 12 & 13 \\
\hline Tendon sheath infections & 7 & $20 \cdot 9$ & $10^{*}$ & $34 \cdot 1$ & 25 & 30 \\
\hline Paronychiae & 6 & $6 \cdot 3$ & 26 & $7 \cdot 7$ & - & - \\
\hline
\end{tabular}

* Excluding one bad case which healed in 180 days.

Infections of the hand call for accurate diagnosis, careful and thorough surgery, and good supporting treatment and follow-up. A sympathetic approach to the patient's domestic and economic problems is important. Such work should not be relegated, as it so often is, to the unsupervised activities of junior house surgeons.

The results obtained suggest that a further trial of the method is indicated.

\section{SUMMARY}

1. A report is presented of the method and results of treatment of sixty-nine consecutive cases of infection of the hand.

2. Excision and primary suture, combined with chemotherapy and immobilisation in plaster, was the method of treatment.

3. The results, from the point of view of rapidity and completeness of recovery, justify consideration of the method for further use.

\section{REFERENCES}

Florey, M. E., and Williams, R. E. O. (1944): Lancet, $1,73$.

CurR, J. F. (1945): Edinburgh Medical Journal, 52, 469.

The authors wish to thank Sir Hugh Cairns, Nuffield Professor of Surgery, for his encouragement and help in the preparation and publication of this paper. 